\title{
MULTIMEDIA BERJENIS INTERAKTIF MATERI INDAHNYA KEANEKARAGAMAN BUDAYA DI NEGERIKU UNTUK KELAS IV
}

\author{
Novia Kuswidayani, I Nyoman Sudana Degeng, Agus Wedi \\ Jurusan Teknologi Pendidikan, Fakultas Ilmu Pendidikan, Universitas Negeri Malang \\ Jalan Semarang 5 Malang 65145 0341-574700 \\ Email:noviakuswi@gmail.com
}

Article History

Received: 20 November 2020, Accepted: 12 Maret 2021, Published: 10 Agustus 2021

\begin{abstract}
Abstrak
Multimedia berjenis interaktif merupakan salah satu alternatif media yang dapat membantu murid belajar secara mandiri. Penelitian ini mempunyai tujuan untuk menciptakan media pembelajaran multimedia berjenis interaktif materi indahnya keanekaragaman budaya negeriku untuk kelas 4 yang tepat murid gunakan untuk belajar. Penelitian tersebut adalah jenis penelitian dan pengembangan (Research and Development). Model yang digunakan dalam penelitian ini adalah model pengembangan Lee \& Owens (2004). Setelah melakukan uji coba terhadap ahli pada media dan ahli pada materi yang memilih ketegori Baik hingga Sangat Baik, dan tanggapan murid yang mempunyai peran sebagai pengguna media pembelajaran memilih kategori Baik hingga Sangat Baik terhadap angket yang telah dibagikan yang berkaitan dengan multimedia berjenis interaktif yang telah dikembangkan. Dengan hasil yang diperoleh menunjukkan bahwa multimedia berjenis interaktif, pokok bahasan indahnya keanekaragaman budaya negeriku yang dikembangkan layak digunakan dalam kegiatan pembelajaran dan dapat menjadi alternatif sumber belajar IPS untuk murid kelas IV.
\end{abstract}

Keyword: Multimedia, Interaktif, Kelas IV

\begin{abstract}
Interactive multimedia is an alternative media that can help students learn independently. This study aims to create a media for interactive multimedia learning about the beauty of cultural diversity in my country for grade 4 which is appropriate for students to use for learning. This research is a type of research and development (Research and Development). The model used in this study is the Lee \& Owens (2004) development model. After conducting trials on experts in media and experts in material who chose the Good to Very Good categories, and the responses of students who had a role as media users for learning chose the Good to Very Good category to the questionnaires that had been distributed related to interactive multimedia which has been developed. The results obtained indicate that interactive multimedia, the subject of the beauty of cultural diversity in my developed country, is suitable for use in learning activities and can be an alternative source of social studies learning for grade IV students.
\end{abstract}

Keyword: Multimedia, Interactive, Class IV 


\section{PENDAHULUAN}

Di dalam pendidikan tentunya ada proses pembelajaran. Pembelajaran merupakan usaha membantu murid dalam aktivitas belajar. Proses komunikasi yang bertujuan untuk menyampaikan pesan antara murid dan guru disebut pembelajaran (Sukoco, Arifin, Satiman \& Wakid, 2014). Tujuan pembelajaran digunakan untuk mewujudkan efektivitas aktivitas belajar yang dilakukan murid. Tujuan pembelajaran dapat dikatakan tercapai apabila murid dapat memahami dan menguasai materi yang disampaikan oleh guru. Proses pembelajaran menjadi kegiatan tanpa arah dan menjadi tidak efektif apabila tujuan pembelajarannya tidak jelas. Perumusan tujuan pernbelajaran menjadi acuan untuk menentukan jenis sistem pembelajaran yang digunakan. Pada kegiatan pembelajaran zaman sekarang ini banyak dpoinui metode dan cara mengajar guru yang sangat mendukung perkembangan pemahaman murid. Akan tetapi, guru yang professional diharuskan mempunyai kemampuan yang lebih sehingga dapat berpengaruh terhadap perkembangan muridnya. Guru juga harus membimbing dan menjadi fasilitator untuk membantu mentransformasikan potensi murid menjadi kemampuan yang ketika dikembangkan dapat berguna bagi manusia. Bukan hanya itu saja, guru harus memberikan peluang bagi murid untuk aktif dalam proses pembelajaran (Fitriyadi, 2013). Dalam aktivitas belajar guru dituntut untuk memberikan inovasi baru agar murid mampu mendapatkan pengalaman baru, inovasi ini diperlukan untuk meningkatkan motivasi murid aktif dalam kegiatan pembelajaran (Fatmala \& Yelianti, 2016).

Dengan digunakannya media pembelajaran sebagai alat perantara dalam aktivitas belajar merupakan salah satu inovasi yang dapat diciptakan. Dengan adanya media pembelajaran dalam aktivitas belajar membuat suasana di kelas menjadi berbeda. Tayangan berupa teks, suara, gambar dan video dapat ditampilkan sehingga guru tidak hanya menggunakan metode ceramah saja (Putri \& Sibuea, 2014). Kegiatan pembelajaran terasa membosankan apabila media pembelajaran tidak dimanfaatkan. Media dapat membuat suatu proses pembelajaran berjalan dengan efektif serta dapat mencegah terjadinya miskonsepsi dalam kegiatan pernbelajaran (Astuti, Cahyono, Supartono, Van \& Duong, 2018). Media pembelajaran yang digunakan guru saat ini masih menggunakan buku dan papan tulis sebagai sedangkan metode yang digunakan sebagian besar yaitu metode ceramah. Semakin pesatnya perkembangan teknologi saat ini banyak software maupun hardware yang dapat dimanfaatkan untuk mengembangkan media pernbelajaran. Hal ini bertujuan untuk menciptakan media pembelajaran yang menarik dan juga memudahkan guru dalam meningkatkan pemahaman murid dalam menyerap materi yang diajarkan. Dengan digunakannya perantara seperti komputer dapat membuat murid tertarik mempelajari materi yang diajarkan (Ali, 2009). Dalam merancang dan mengevaluasi pembelajaran keberadaan komputer juga sangat membantu guru (Fanny \& Suardiman, 2013).

Aktivitas belajar yang membosankan berubah menjadi menyenangkan dengan dimanfaatkannya media pembelajaran berbasis multimedia berjenis interaktif. Oleh karena itu sumber belajar murid tidak melalui guru saja serta multimedia berjenis interaktif diharapkan membuat murid aktif dalam belajar (Illahi, Sukartiningsih \& Subroto, 2018). Multimedia berjenis interaktif dapat membuat murid tertarik dalam belajar dan juga dapat meningkatkan motivasi belajar murid. Dengan menggunakan multimedia berjenis interaktif, murid dapat belajar secara mandiri, sehingga belajar bisa dilakukan kapan saja.

Pada penelitian (Fanny \& Suardiman, 2013) dikatakan bahwa dengan digunakannya media pembelajaran multimedia berjenis interaktif dalam aktivitas belajar bisa meningkatkan prestasi belajar murid. Dalam penelitian lain (Arinda, 2016) dikatakan bahwa dengan menampilkan materi berupa integrasi teks, suara, gambar bergerak dan video dapat membuat suasana kelas menjadi menyenangkan pada kelas pada saat proses belajar. Pada penelitian kali ini, bertujuan mengembangkan media pembelajaran berbasis multimedia berjenis interaktif pada mata pelajaran Ilmu Pengetahuan Sosial. 
Ilmu pengetahuan sosial merupakan bagian dari kurikulum sekolah. Mata pelajaran tersebut membantu murid dalam memecahkan permasalahan yang dihadapi sehingga akan menjadikan murid mengerti dan memahami lingkungan sosial masyarakatnya. Tujuan pelajaran IPS diantaranya murid dapat memiliki keteguhan dan kesadaran terhadap nilai-nilai sosial dan kemanusiaan serta dapat memiliki kemampuan berkomunikasi, bekerja sama serta berkompetensi dalam masyarakat yang majemuk di tingkat nasional maupun global. Oleh karena itu, agar tujuan pembelajaran IPS dapat tercapai, kurikulum pendidikan menuntut murid untuk lebih aktif dalam kegiatan pembelajaran. Pada penelitian (Arinda, 2016) permasalahan dapat diatasi apabila mengintegrasikan teknologi pembelajaran dalam proses belajar mengajar seperti penggunaan multimedia berjenis interaktif.

Pelaksanaan pembelajaran IPS di Sekolah Dasar harus memperhatikan konsep atau pokok bahasan dan perkembangan berpikir murid. Menurut penelitian (Fanny \& Suardiman, 2013) pembelajaran IPS dianggap sulit dan kurang menarik oleh peserta didik, guru belum begitu optimal menggunakan media dalam pembelajaran IPS, pendidik belum mampu membuat dan mengembangkan software pembelajaran multimedia berjenis interaktif. Dari permasalahan yang terjadi di lapangan, dapat dikatakan bahwa pembelajaran IPS dirasa sangat membosankan apabila guru hanya menyampaikan materi pelajaran dengan metode ceramah saja sehingga berdampak pada hasil belajar murid yang kurang memuaskan. Selain itu, penggunaan media pembelajaran di sekolah masih kurang optimal. Pernyataan ini didasarkan pada observasi yang telah dilakukan di SDIT Al-Hikmah Bence.

Berdasarkan uraian tersebut, penelitian akan mengembangkan sebuah media pembelajaran berbasis multimedia berjenis interaktif dengan menggunakan aplikasi Articulate Storyline 3. Pengembangan media pembelajaran dilakukan pada materi pelajaran Indahnya Keanekaragaman Budaya negeriku agar dapat disampaikan secara menarik, sehingga pembelajaran tidak monoton dan membosankan. Media ini dapat digunakan untuk murid kelas IV SD. Penelitian ini bertujuan untuk mengembangkan media pembelajaran multimedia berjenis interaktif mata pelajaran IPS yang layak digunakan dalam proses belajar di sekolah.

\section{METODE}

Metode yang digunakan dalam penelitian ini adalah penelitian dan pengembangan (Research and Development) atau dapat disingkat $\mathrm{R} \& \mathrm{D}$. Tujuan dari penelitian ini yaitu menciptakan sebuah media pembelajaran multimedia berjenis interaktif yang layak, oleh karena itu model penelitian dan pengembangan ini menggunakan model pengembangan multimedia menurut (Lee \& Owens, 2004). Model Lee \& Owens mempunyai beberapa tahapan, seperti tersaji pada gambar 1.

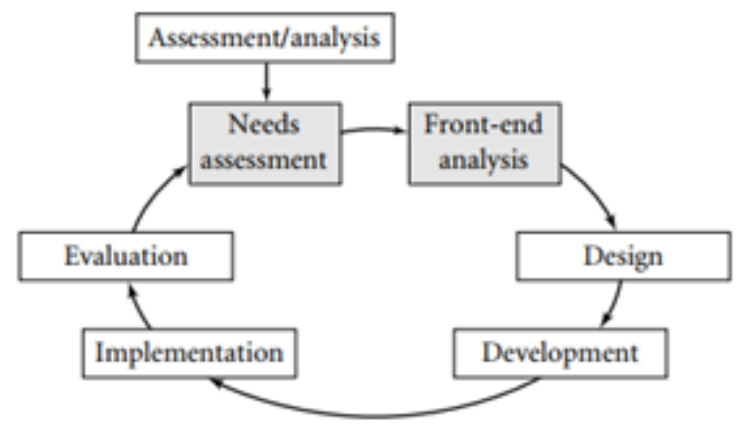

\section{Gambar 1. Model Pengembangan Lee \& Owens (2004)}

Tahap analilis dibagi menjadi dua, yaitu analisis suatu kebutuhan (Need Assessment) dan analisis di awal dan di akhir (Front-end Analysis). Pada tahap analisis awal dan di akhir mempunyai 10 analisis. Sedangkan pada tahap desain (Design) yang berisikan tahap perencanaan media yang dapat dikembangkan. Tahap berikutnya yaitu tahap pengembangan (Development) berisikan tahap pengembangan sebuah produk multimedia berjenis interaktif. Tahap berikutnya yaitu implementasi (Implementation) dan tahap yang terakhir evaluasi (Evaluation). sedangkan penelitian kali ini hanya 
selesai di tahap pengembangan (Development) yang selanjutnya diujicobakan ke ahli pada media, ahli pada materi dan respon murid sebagai pengguna.

Penelitian dan pengembangan ini memiliki sasaran penelitian yaitu murid kelas 4 SDIT AlHikmah Bence yang berjumlah 3 responden. Media yang sebelumnya dikembangkan sudah diuji kelayakan oleh ahli pada media yakni, merupakan dosen Teknologi Pendidikan Universitas Negeri Malang serta ahli pada materi yakni, merupakan guru IPS pada kelas 4 SDIT Al-Hikmah Bence. Penelitian ini menggunakan teknik analisis data berupa skor angket meliputi penilaian yang diajukan ke ahli pada media, ahli pada materi, serta murid. Angket uji coba yang ditujukan pada ahli pada media terdapat 20 bentuk pernyataan, ahli pada materi terdapat 20 bentuk pernyataan, dan murid terdapat 10 bentuk pernyataan. Tipe data yang dipergunakan adalah kuantitatif serta kualitatif.

\section{HASIL}

Data dalam hasil uji coba terhadap multimedia berjenis interaktif dihasilkan dari penilaian yang dilaksanakan ahli pada media dan ahli pada materi. Berikutnya diujicobakan ke murid sebagai pengguna media bagi pembelajaran. Data yang diambil dari penelitian dan pengembangan memakai pendekatan kuantitatif serta kualitatif yaitu memakai angket (questionnaire).

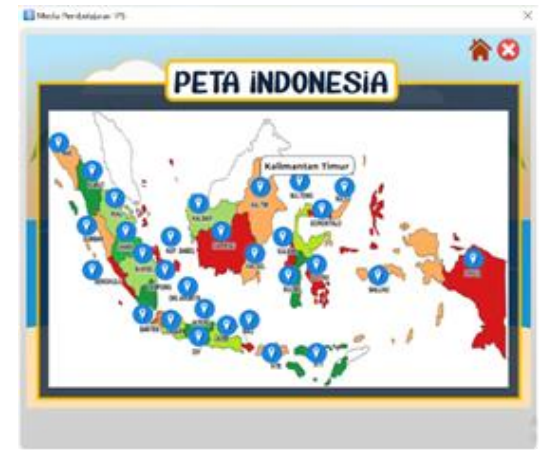

\section{Gambar 2. Tampilan Multimedia Interaktif}

Produk pengembangan multimedia berjenis interaktif ini berguna untuk menaikkan minat murid saat belajar pelajaran IPS materi indahnya keanekaragaman budaya negeriku. Pada tahap analisis dilakukan observasi dan wawancara kepada guru pelajaran IPS kelas IV SD. Observasi serta wawancara dilakukan untuk menganalisis permasalahan murid kelas IV SDIT Al-Hikmah Bence. Pada tahap ini permasalahannya yaitu murid kurang fokus dan mengalami kesulitan dalam belajar menghafal aneka ragam budaya di Indonesia. Selanjutnya merencanakan produk yang dikembangkan sesuai dengan yang dibutuhkan murid kelas IV. Tahap selanjutnya yaitu mengembangkan produk sesuai dengan rancangan yang telah dibuat. Gambar 2 memperlihatkan antarmuka (Interface) produk multimedia berjenis interaktif yang dikembangkan.

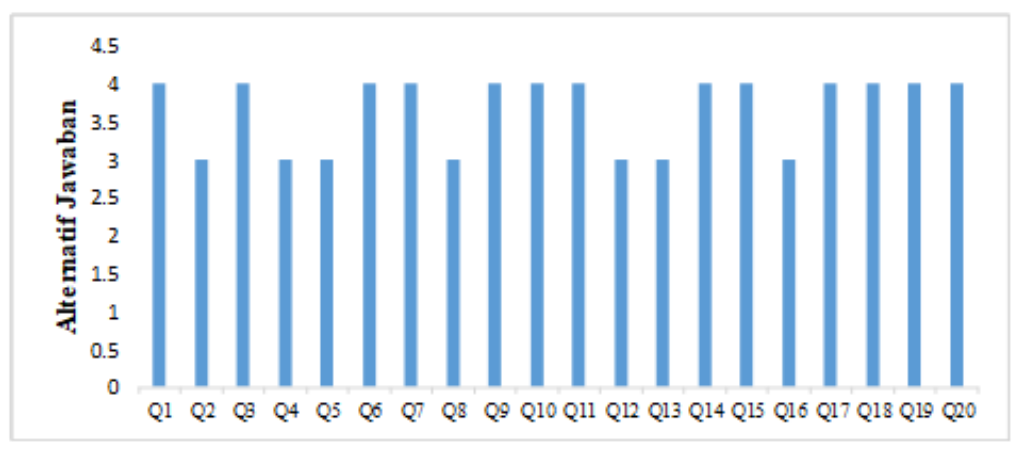

Grafik 1. Diagram Batang Tanggapan Ahli pada media 
Setelah produk sudah dikembangkan, selanjutnya dilakukan uji coba kepada ahli pada materi, dan murid. Uji coba ini dilakukan guna mengetahui kelayakan media pembelajaran yang telah dikembangkan.

Dari hasil uji coba kepada ahli pada media diperoleh hasil untuk data kuantitatif, bahwa dari 20 pernyataan yang diberikan 13 bentuk pernyataan memilih Sangat Baik yang memiliki bobot sebesar (4) yakni pada pernyataan berikut: Ketepatan pemilihan background; Konsistensi penempatan button, Ketepatan warna huruf dalam teks, Kemenarikan cover media pembelajaran, Kualitas tampilan gambar, Kesesuaian warna background dengan teks, Ketepatan ukuran gambar, Kejelasan tombol navigasi, Konsistensi penggunaan tombol, Kecepatan program, Kemenarikan media pembelajaran, Kemudahan penggunaan media pembelajaran, Kemudahan dalam memilih sajian menu. Sedangkan 7 poin pernyataan memilih Baik yang memiliki bobot sebesar (3) yakni pada pernyataan berikut: Kejelasan petunjuk penggunaan, Ketepatan jenis huruf dalam teks, Ketepatan ukuran huruf dalam teks, Terdapat penekanan kata pada poin penting, Ketepatan pemilihan video dengan materi, Kualitas video, Kejelasan petunjuk penggunaan. Berdasarkan analisis yang dilakukan terhadap responden ahli pada media maka Multimedia berjenis interaktif Materi Indahnya Keanekaragaman Budaya Negeriku Untuk Kelas IV Layak digunakan sebagai media pembelajaran. Untuk data kualitatif berisi komentar dan saran yang di berikan oleh ahli pada media. Komentar dan saran yang diperoleh diantaranya: secara umum media yang dikembangkan cukup bagus dan sebaiknya dilengkapi dengan pencantuman sumber/referensi/credit tittle. Dengan adanya komentar dan saran yang diberikan oleh ahli pada media diharapkan mampu meningkatkan kelayakan media pembelajaran multimedia berjenis interaktif untuk selanjutnya.

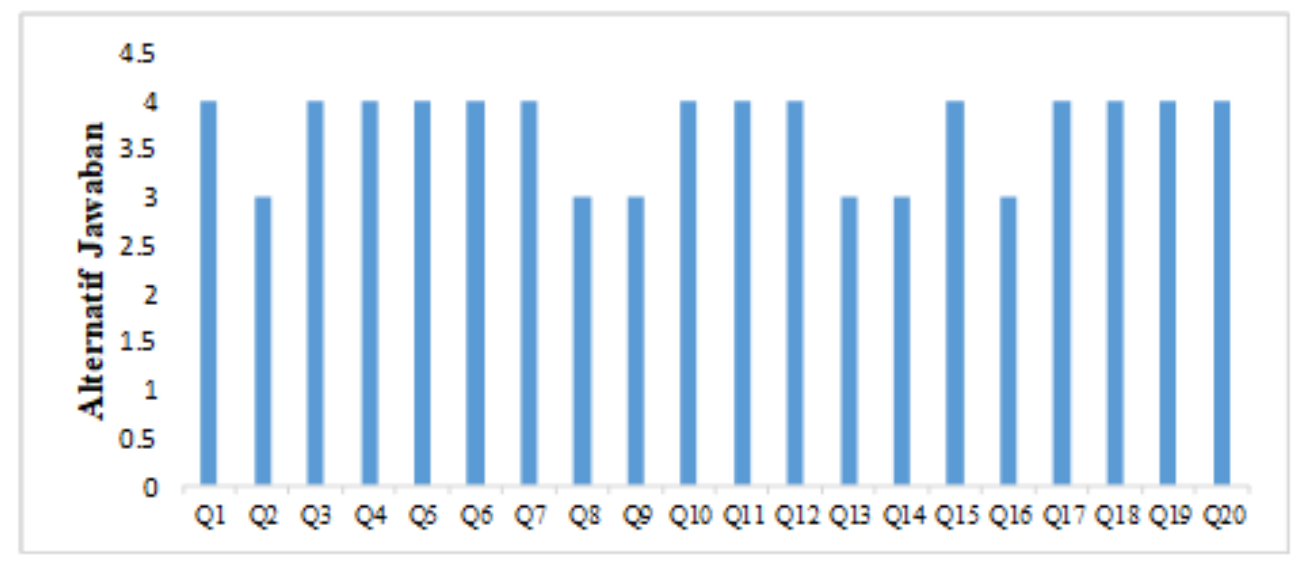

Grafik 2. Diagram Batang Tanggapan Ahli pada materi

Dari hasil uji coba kepada ahli pada media diperoleh hasil untuk data kuantitatif, bahwa dari 20 pernyataan yang diberikan 14 poin pernyataan memilih Sangat Baik yang memiliki bobot sebesar (4) yakni pada pernyataan berikut: Kesesuaian materi dengan KD, Kejelasan penyajian materi, Kebenaran materi, Rumusan soal sesuai dengan KD, Menuntut aktivitas murid, Memberi kesempatan murid belajr

mandiri, Kejelasan penggunaan bahasa, Gambar yang disajikan mendukung materi, Keruntutan penyajian materi, Kemenarikan penyajian materi, Proporsi soal latihan, Kualitas penyajian materi, Kesesuaian bahasa dengan sasaran pengguna, Kesesuaian penyajian contoh. Sedangkan 6 poin pernyataan memilih Baik yang memiliki bobot sebesar (3) yakni pada pernyataan berikut: Kesesuaian materi dengan indikator, Kesesuaian media dengan karakteristik murid, Kejelasan uraian materi, Kemenarikan judul, Petunjuk belajar, Kecukupan pemberian umpan balik. Berdasarkan analisis yang dilakukan terhadap responden ahli pada media maka dapat dikatakan bahwa Multimedia berjenis interaktif Materi Indahnya Keanekaragaman Budaya Negeriku Untuk Kelas IV Layak digunakan sebagai media pembelajaran. Untuk data kualitatif berisi komentar dan saran yang di berikan oleh ahli pada media. Komentar dan saran yang diperoleh diantaranya: dalam penyajian video perlu ditambah 
suara agar lebih jelas dan menarik. Dengan adanya komentar dan saran yang diberikan oleh ahli pada materi diharapkan mampu meningkatkan kelayakan media pembelajaran multimedia berjenis interaktif untuk selanjutnya.

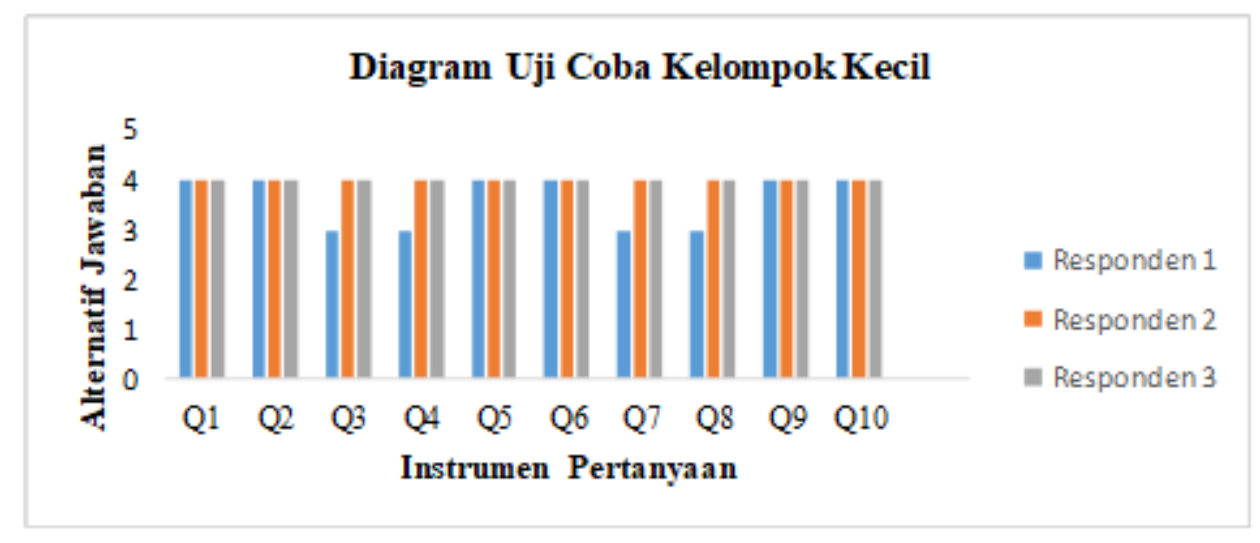

\section{Grafik 3. Diagram Batang Tanggapan Murid}

Dari hasil uji coba kepada 3 murid yang berperan sebagai pengguna media pembelajaran diperoleh hasil dari 10 poin pernyataan yang diberikan sebanyak 2 murid yang memberikan bobot (4) pada 10 poin pernyataan dan 1 murid memberikan bobot (3) pada 4 poin pernyataan dan bobot (4) pada 6 poin pernyataan. Berdasarkan analisis yang dilakukan kepada ketiga responden dapat dikatakan bahwa Multimedia berjenis interaktif Materi Indahnya Keanekaragaman Budaya Negeriku Untuk Kelas IV Layak digunakan sebagai media pembelajaran.

\section{PEMBAHASAN}

Penelitian dan pengembangan dilaksanakan bertujuan mengembangkan multimedia berjenis interaktif materi Indahnya Keanekaragaman Budaya negeriku yang layak dipakai sebagai media pembelajaran. Media pembelajaran merupakan perantara yang mempunyai tujuan menyampaikan ide serta gagasan sehingga tersampaikan kepada yang dituju (Arsyad, 2013). Mutu pendidikan dapat ditingkatkan dengan memakai media pembelajaran dalam aktivitas belajar sebagai perantara dalam mencari sumber belajar serta hal ini berpengaruh terhadap waktu belajar menjadi lebih fleksibel (Wulandari, Sibuea \& Siagian, 2018). Media pembelajaran merupakan suatu hal yang dapat menyampaikan informasi yang bertujuan supaya aktivitas belajardapat berjalan efektif serta efisien (Istiqlal, 2017). Media pembelajaran dapat digunakan sebagai alat pembangkit motivasi dan perhatian murid melalui interaksi langsung antara murid dengan sumber belajar (Heriyanto, Haryani \& Sedyawati, 2014). Media pembelajaran dapat dipakai sebagai alat komunikasi agar aktivitas belajar mengajar berjalan efektif. Media pembelajaran yang dimanfaatkan secara kreatif diharapkan mampu meningkatkan efektivitas pembelajaran (Arda, Soehana \& Darsikin, 2015). Materi pelajaran diharapkan mudah dipahami oleh murid apabila menggunakan media pembelajaran. Murid menjadi lebih tertari belajar apabila menggunakan media pembelajaran sebagai perantara dalam menyampaikan isi materi (Putri, Risdianto \& Rohadi, 2019). Penggunaan media pembelajaran dalam proses belajar juga memberikan pengaruh yang sangat baik terhadap daya tarik dan minat murid ketika mempelajari sesuatu (Ditama, Saputro \& Catur, 2015). Hasil penelitian (Yunita, Praherdhiono, \& Adi, 2019) menunjukkan bahwa media pembelajaran sangat penting digunakan dalam proses pembelajaran, dengan teknologi yang semakin berkembang pesat, media juga mengalami perkembangan yang pesat. Terdapat banyak media yang bisa digunakan oleh guru guna menyampaikan isi materi, salah satunya adalah media pembelajaran yang menggunakan teknologi komputer contohnya multimedia berjenis interaktif (Sanusi, Suprapto \& Apriandi, 2015).

Multimedia berjenis interaktif adalah media yang menggabungkan teks, grafik, video, animasi dan suara untuk menyampaikan suatu pesan dan informasi, melalui media elektronik seperti komputer 
dan perangkat elektronik lainnya (Handayani, Sihkabuden \& Praherdhiono, 2018). Multimedia melibatkan lebih dari sekedar pengintegrasian bentuk-bentuk tersebut kedalam suatu program terstruktur, yang terdiri dari unsur-unsur yang saling melengkapi satu sama lain (Novana, Sukaesih \& Prasetyo, 2012). Multimedia berjenis interaktif merupakan media yang sangat baik memberikan kesempatan murid untuk mengembangkan soft skill, mengidentifikasi masalah, menganalisis, mengevaluasi, dan mengkomunikasikan informasi (Widayat, Kasmui \& Sukaesih, 2014). Multimedia merupakan sistem komputer yang terdiri dari perangkat keras dan perangkat lunak yang memudahkan dalam menggabungkan gambar, video, grafik, suara, animasi, dan teks yang dikendalikan oleh program komputer (Wiana, 2017). Menurut Azhar Arsyad (2004) murid yang lamban menerima pembelajaran dapat memanfaatkan komputer memberikan iklim yang lebih bersifat afektif dengan cara yang lebih individual dan tidak membosankan. Multimedia berjenis interaktif dilengkapi dengan alat pengontrol yang dapat dijalankan oleh pengguna, sehingga pengguna dapat memilih apa yang diinginkan sehingga proses belajar menjadi menarik (Wiyana, 2013). Multimedia sebagai alat penyempurnaan metode pembelajaran yang dipakai guru pada saat mengajar sehingga dapat menarik perhatian murid untuk belajar (Nusir, Alsmadi, Al-Kabi \& Sharadgah, 2013). Multimedia berjenis interaktif sangat membantu untuk pemahaman murid terkait materi pelajaran yang bersifat abstrak (Dewi \& Haryanto, 2018).

Hasil penelitian (Saifudin, Susilaningsih, \& Wedi, 2020) menunjukkan bahwa penggunaan multimedia berjenis interaktif dapat meningkatkan pemahaman murid terhadap materi. Hal ini dibuktikan dengan skor hasil penelitian yang diperoleh yaitu validasi ahli pada media 93,7\%, ahli pada materi 93,7\%, dan skor hasil uji coba murid $100 \%$ maka, dapat dikatakan bahwa media pembelajaran yang dikembangkan tergolong layak digunakan. Pada penelitian (Nafi'a, Degeng, \& Soepriyanto, 2020) dikatakan multimedia berjenis interaktif merupakan media pembelajaran yang sangat baik digunakan dalam proses belajar di dalam kelas. Hal ini sesuai dengan rata-rata hasil kelayakan media pembelajaran yang telah diujicobakan kepada ahli pada materi, ahli pada media, dan guru mata pelajaran IPS dengan hasil 92,66\%. Hasil tersebut tergolong layak atau valid digunakan.

Hasil penelitian (Rofiq, Mahadewi, \& Parmiti, 2019) menyatakan bahwa media pembelajaran multimedia berjenis interaktif sangat efektif untuk meningkatkan hasil belajar murid yang dibuktikan oleh hasil uji coba yang telah dilakukan kepada ahli dan murid. Hasil uji coba yang di lakukan pada ahli isi pembelajaran meperoleh hasil $90 \%$ yang termasuk pada kategori sangat baik, ahli desain pembelajaran $86,67 \%$ termasuk kategori baik, ahli pada media pembelajaran $92 \%$ termasuk kategori sangat baik, uji coba perorangan 92,67\% termasuk kategori sangat baik, uji coba kelompok kecil 93,3\% termasuk kategori sangat baik, dan uji coba lapangan 94,2\% termasuk kategori sangat baik.

Media pembelajaran multimedia berjenis interaktif terbukti secara nyata dapat membantu guru dalam menyampaikan materi pembelajaran. Dengan adanya media pembelajaran multimedia berjenis interaktif diharapkan dapat meningkatkan hasil belajar dan minat belajar murid terhadap mata pelajaran IPS materi Indahnya Keanekaragaman budaya negeriku. Hal ini dikarenakan materi disajikan secara menarik dan interaktif sehingga murid terdorong untuk memahami materi yang diajarkan oleh guru. Pengguanan multimedia berjenis interaktif merupakan salah satu alternatif untuk meningkatkan kualitas pembelajaran di kelas (Wardani, Setyosari, \& Husna, 2019).

Hasil penelitian yang telah dilakukan bahwa penggunaan media pembelajaran multimedia berjenis interaktif dalam proses pembelajaran sangat membantu guru dalam menyampaikan isi materi pelajaran. Multimedia berjenis interaktif dapat meningkatkan minat murid untuk memahami isi materi sehingga dapat meningkatkan hasil belajar. Multimedia berjenis interaktif juga dapat memungkinkan murid untuk mengualangi isi materi yang ada di dalamnya. Sesuai dengan pernyataan Rokhayani, Kuswandi, \& Abidin (2019) dalam pembelajaran melalui multimedia berjenis interaktif, murid dimungkinkan untuk melakukan pengulangan materi yang sudah dipaparkan atau dijelaskan. 
Media pembelajaran multimedia berjenis interaktif materi Indahnya Keanekaragaman Budaya negeriku untuk kelas IV dikembangkan dengan melakukan penyesuaian tertentu, multimedia berjenis interaktif yang dikembangkan dimanfaatkan sebagai alat bantu belajar murid mata pelajaran IPS materi Indahnya Keanegaragaman Budaya negeriku. Pengembangan media pembelajaran ini berlandaskan perolehan hasil uji coba ahli pada media, ahli pada materi serta tanggapan murid sebagai pengguna.

Multimedia berjenis interaktif materi indahnya keanekaragaman budaya negeriku untuk kelas IV yang diujicobakan kepada ahli pada media, ahli pada materi dan murid dapat dikatakan layak digunakan sebagai media pembelajaran. Hal ini berdasarkan hasil uji coba kepada ahli, yaitu pada angket ahli pada media dalam skala bobot 1-4 memberikan bobot (3) pada 7 poin pernyataan dan memberikan bobot (4) pada 13 poin pernyataan. Sedangkan pada angket ahli pada materi dalam skala bobot 1-4 memberikan bobot (3) pada 6 poin pernyataan dan memberikan bobot (4) pada 14 poin pernyataan.

Diharapkan untuk pengembang selanjutnya dapat mengembangkan media pembelajaran multimedia berjenis interaktif yang isi materinya lebih lengkap dan lebih detail lagi. Dalam segi desain dapat membuat yang lebih menarik lagi agar murid bersemangat untuk belajar.

\section{SIMPULAN}

Multimedia berjenis interaktif materi indahnya keanekaragaman budaya negeriku dapat dijadikan solusi guna memecahkan permasalahan dalam proses pembelajaran yang sampai saat ini kebanyakan sekolah masih menggunakan metode konvensional atau ceramah. Multimedia berjenis interaktif ini memiliki kelebihan yaitu murid dapat mengoperasikan secara langsung sesuai dengan panduan buku petunjuk pemanfaatan. Hal ini dapat menarik perhatian murid dalam proses belajar karena murid dapat dengan leluasa mengoperasikan multimedia berjenis interaktif dan dapat mengulangi materi pelajaran yang dirasa kurang paham. Berdasarkan hasil uji coba yang dilakukan kepada ahli pada media, ahli pada materi, dan murid yang seluruhnya memenuhi kriteria layak, sehingga dapat ditarik kesimpulan bahwa multimedia berjenis interaktif materi Indahnya Keanegaraman Budaya negeriku dapat dikatakan layak digunakan sebagai media pembelajaran. Hal ini dapat dibuktikan dengan angket ahli pada media dan ahli pada materi yang memeberikan jawaban dengan bobot (3) dengan kriteria Baik sampai dengan bobot (4) dengan kriteria Sangat Baik. Serta tanggapan murid yang berperan sebagai pengguna yang menunjukkan ketertarikan terhadap media pembelajaran yang dikembangkan. Hal ini dibuktikan dengan angket tanggapan murid yang memilih alternative jawaban dengan bobot (3) dengan kriteria Baik sampai dengan bobot (4) dengan kriteria Sangat Baik.

\section{DAFTAR RUJUKAN}

Ali, M. (2009). Pengembangan Media Pembelajaran Interaktif Mata Kuliah Medan Elektromagnetik. Jurnal Edukasi Elektro, 5(1), 11-18.

Arda., Saehana, S., \& Darsikin. (2015). Pengembangan Media Pembelajaran Interaktif Berbasis Komputer Untuk Murid SMP Kelas VII. e-Jurnal Mitra Sains, 3 (1), 69-77.

Arikunto, S. (2010). Prosedur Penelitian Suatu Pendekatan Praktik. Jakarta: Rineka Cipta.

Arinda, F. D. (2016). Pengembangan Multimedia Pembelajaran Interaktif Ilmu Pengetahuan Sosial SMP. Jurnal Inovasi dan Teknologi Pembelajaran, 1 (4), 302-306.

Arsyad, A. 2013. Media Pembelajaran. Jakarta: Rajawali Press.

Astuti, F. K., Cahyono, E., Supartono., Van, N. C., \& Duong, T. D. (2018). Effectiveness Of Elements Periodic Table Interactive Multimedia In Nguyen Tat Thanh High School. International Journal of Indonesian Education and Teaching, 2 (1), 1-10.

Azhar Arsyad. 2004. Media Pembelajaran. Jakarta: Raja Grafindo Persada 
Dewi, S. R., \& Haryanto, H. (2018). Pengembangan Multimedia Interaktif Penjumlahan Pada Bilangan Bulat Untuk Murid Kelas IV Sekolah Dasar. Premiere Educandum: Jurnal Pendidikan Dasar dan Pembelajaran, 9 (1), 9-22.

Ditama, V., Saputro, S., \& Catur, A. N. (2015). Pengembangan Multimedia Interaktif Dengan Menggunakan Program Adobe Flash Untuk Pembelajaran Kimia Materi Hidrolisis Garam SMA Kelas XI. Jurnal Pendidikan Kimia, 4 (2), 23-31.

Fanny, A. M., \& Suardiman, S. P. (2013). Pengembangan Multimedia Interaktif Untuk Mata Pelajaran Ilmu Pengetahuan Sosial (IPS) Sekolah Dasar Kelas V. Jurnal Prima Edukasia, 1 (1), 1-9.

Fatmala, D., \& Yelianti, U. (2016). Pengembangan Media Pembelajaran Multimedia Interaktif Berbasis Android Pada Materi Plantae Untuk Murid SMA Menggunakan Eclipse Galileo. BIODIK, 2 (1).

Fitriyadi, H. 2013. Integrasi Teknologi Informasi Komunikasi dalam Pendidikan: Potensi Manfaat, Masyarakat Berbasis Pengetahuan, Pendidikan Nilai, Strategi, Implementasi dan Pengembangan Profesional. Jurnal Pendidikan Teknologi dan Kejuruan, 21 (3), 271-272.

Handayani, S. N., Sihkabuden., \& Praherdhiono, H. (2018). Pengembangan Multimedia Interaktif Seni Tari Jawa Timur Pada Mata Pelajaran Seni Budaya Kelas VII di SMP Negeri I Karangan. Jurnal Kajian Teknologi Pendidikan, 1 (1), 63-69.

Heriyanto, A., Haryani, S., \& Sedyawati, S. M. R. (2014). Pengembangan Multimedia Pembelajaran Interaktif Berbasis Education Game Sebagai Media pembelajaran Kimia. Chemistry in Educatuon, 3 (1), 1-7.

Illahi, T. A. R., Sukartiningsih, W., \& Subroto, W. T. (2018). Pengembangan Multimedia Interaktif Pada Pembelajaran Materi Jenis-jenis Pekerjaan Untuk Meningkatkan Kemampuan Berpikir Kritis. Jurnal Review Pendidikan Dasar: Jurnal Kajian Pendidikan dan Hasil Penelitian, 4 (3).

Istiqlal, M. (2017). Pengembangan Multimedia Interaktif Dalam Pembelajaran Matematika. Jurnal Ilmiah Pendidikan Matematika, 2 (1).

Lee, W. W., \& Owens, D. L. (2004). Multimedia-Based Instructional Design, (2nd Ed.) SanFransisco: Pffeiffer

Nafi'a, M. Z. I., Degeng, I. Y. S., \& Soepriyanto, Y. (2020). Pengembangan Multimedia Interaktif Materi Perkembangan Kemajuan Teknologi Pada Mata Pelajaran Ilmu Pengetahuan Sosial. Jurnal Kajian Teknologi Pendidikan, 3 (3), 272-281.

Novana, T., Sukaesih, S., \& Prasetyo, A. P. B. (2012). Pengembangan Multimedia Interaktif Berbahasa Inggris Materi Vertebrata Sebagai Suplemen Pembelajaran Di SMA. Unnes Journal of Biology Education, 1 (1), 40-46.

Nusir, S., Alsmadi, I., Al-Kabi, M., \& Sharadgah, F. (2013). Studying The Impact Of Using Multimedia Interactive Programs On Children's Ability To Learn Basic Math Skills. ELearning and Digital Media, 10 (3), 305-319.

Putri, I. P., \& Sibuea, A. M. (2014). Pengembangan Media Pembelajaran Interaktif Pada Mata Pelajaran Fisika. Jurnal Teknologi Informasi \& Komunikasi dalam Pendidikan, 1 (2), 145-155.

Putri, R. M., Risdianto, E., Rohadi, N. (2019). Pengembangan Media Pembelajaran Interaktif Dengan Menggunakan Adobe Captivate Pada Materi Gerak Harmoni Sederhana. Jurnal Kumparan Fisika, 2 (2), 113-120.

Rachmawati, F. (2018). Pengembangan Multimedia Interaktif Untuk Pembelajaran Mengenal Jenisjenis Usaha dan Kegiatan Ekonomi di Indonesia Murid Kelas V SD Tahun Ajaran 2017/2018. Jurnal Simki-Pedagogia, 2 (6), 2-9.

Rofiq, A., Mahadewi, L. P. P., \& Parmiti, D. P. (2019). Pengembangan Multimedia Pembelajaran Interaktif Pada Mata Pelajaran IPS Terpadu. Journal Of Education Technology, 3 (3), 126-133.

Rokhayani, D., Kuswandi, D., \& Abidin, Z. (2019). Multimedia Interaktif Berbasis Game Kelas X Sekolah Menengah Atas. Jurnal Kajian Teknologi Pendidikan, 2 (2), 102-108. 
Saifudin, M. F., Susilaningsih., \& Wedi, A. (2020). Pengembangan Multimedia Interaktif Materi Sumber Energi Untuk Memudahkan Belajar Murid SD. Jurnal Kajian Teknologi Pendidikan, 3 (1), 68-77.

Sanusi., Suprapto, E., \&Apriandi, D. 2015. Pengembangan Multimedia Interaktif Sebagai Media pembelajaran Pada Pokok Bahasan Dimensi Tiga Di Sekolah Menengah Atas (Sma). Jurnal Ilmiah Pendidikan Matematika, 3 (2), 398-416.

Septiana, N. (2018). Pengembangan Media Pembelajaran Berbasis Multimedia Interaktif Pada Pemahaman Konsep Murid. PANCAWAHANA: Jurnal Studi Islam, 13 (1), 84-90.

Sukoco., Arifin, Z., Satiman., \& Wakid, M. (2014). Pengembangan Media Pembelajaran Interaktif Berbasis Komputer Untuk Peserta Didik Mata Pelajaran Teknik Kendaraan Ringan. Jurnal Pendidikan Teknologi dan Kejuruan, 22 (2), 215-226.

Wardani, S. K., Setyosari, P., \& Husna, A. (2019). Pengembangan Multimedia Tutorial Mata Pelajaran Ipa Pokok Bahasan Sistem Tata Surya Kelas VII MTS Raudlatul Ulum Karangploso. Jurnal Kajian Teknologi Pendidikan, 2(1), 23-29.

Wiana, W. (2017). Application Design Of Interactive Multimedia Development Based Motion Graphic On Making Fashion Design Learning In Digital Format. International Journal Of Scientific \& Technology Research, 6 (5), 102-108.

Widayat, W., Kasmui., \& Sukaesih, S. (2014). Pengembangan Multimedia Interaktif Sebagai Media pembelajaran IPA Terpadu Pada Tema Sistem Gerak Pada Manusia. Unnes Science Education Journal, 3 (2), 535-541.

Wiyana., Umar, H. S., Usman, A. (2013). Pengembangan Multimedia Untuk Perolehan Belajar Konsep Reproduksi Manusia Dalam Mata Pelajaran Biologi Kelas IX. Jurnal Teknologi Pendidikan, 1-12.

Wulandari, T. A. J., Sibuea, A. M., \& Siagian, S. (2018). Pengembangan Media Pembelajaran Berbasis Multimedia Interaktif Pada Mata Pelajaran Biologi. Jurnal Teknologi Informasi \& Komunikasi dalam Pendidikan, 5 (1), 75-86.

Yunita, R., Praherdhiono, H., \& Adi, E. P. (2019). Pengembangan Multimedia Interaktif Materi Fotosintesis Untuk Murid Kelas VIII Sekolah Menengah Pertama. Jurnal Kajian Teknologi Pendidikan, 2 (4), 284-289. 